\title{
Image Weighting Type
}

National Cancer Institute

\section{Source}

National Cancer Institute. Image Weighting Type. NCI Thesaurus. Code C116122.

A classification of the technique used to enhance image contrast based on differences in magnetic resonance tissue properties. This can be achieved by changing the echo time or repetition time after the tissue has returned to its equilibrium state. 